\title{
Biology of the deep-water crab Paralomis spinosissima (Decapoda: Anomura: Lithodidae) near South Georgia Island, south Atlantic
}

\author{
Robert S. Otto and Richard A. MacIntosh
}

\begin{abstract}
Observations on the lithodid crab, Paralomis spinosissima, were taken during the first exploratory crab fishing near South Georgia Island. We examined $P$. spinosissima from waters near South Georgia Island (4,970 crabs) and from waters near Shag Rocks (190 crabs). Morphometric measurements, reproductive characteristics, incidence of rhizocephalan parasites and the occurrence of microsporidan infections were recorded. Gross examination showed that rhizocephalans infected $15 \%$ of the specimens examined, while microsporidans infected $0.5 \%$. Rhizocephalan parasites were hyper-parasitized by an undescribed species of isopod. Morphometrically, rhizocephalan-infected males resembled females, but parasitized and unparasitized females were similar. Examination of females showed that $50 \%$ were ovigerous at 62 $\mathrm{mm}$ carapace length in both areas, but ovigerous females at South Georgia Island were larger than those at Shag Rocks. Ovigerous females carried embryos in diverse developmental stages, indicating a protracted spawning period, perhaps lasting throughout the year. Chela allometry showed males matured at $75 \mathrm{~mm}$ carapace length at South Georgia Island and $66 \mathrm{~mm}$ at Shag Rocks. Fecundity estimated from preserved egg clutches ranged from 2,569 to 13,745 eggs per female. Eggs averaged $2.08 \mathrm{~mm}$ length and $\mathbf{1 . 8 8}$ mm width, which is considerably larger than that typical shallow water Paralithodes spp. but is smaller than that typical of Lithodes spp.
\end{abstract}

\section{INTRODUCTION}

South Georgia Island is just south of the Antarctic Polar Front on the Scotia Ridge, placing its waters within the Antarctic Zoogeographic Region (Eastman, 1993). Shelf waters of South Georgia Island are relatively shallow and warm by Antarctic standards, and this probably accounts for the nearly unique occurrence of crabs within the zoogeographic region. All four crab species known from the shelf waters of South Georgia Island are anomurans of the family Lithodidae (Macpherson, 1988). None of the crab species found there are endemic, and all are members of genera that are widely spread in deep waters ranging from the outer continental shelf to abyssal regions. By contrast, Eastman (1993) shows that $30 \%$ to $40 \%$ of animal species found near South Georgia Island are endemic.

Exploratory fishing operations by the F/V Pro Surveyor during the summer and fall of 1992 captured all four South Georgia Island crab species. The most common crab in the vessel's catch was Paralomis spinosissima or Antarctic stone crab (in FAO landing statistics) which was the target of this fishery. The next most common species was Paralomis formosa that tended to be taken in slightly deeper water than $P$. spinosissima and was only targeted by the fishery for a brief period. The remaining two species, Neolithodes diomedeae and Paralomis anamerae, were taken but rarely. The crab pots (traps) used may have influenced species composition of the catch, but targeting on $P$. spinosissima by fishing at certain depths and localities was probably more important.

This report describes the biological data on $P$. spinosissima obtained by the authors while serving as observers aboard the F/V Pro Surveyor. Here we record biological conditions found in the population prior to the onset of appreciable directed fishing. Various aspects of exploratory fishing operations in 1992 and subsequently have been described elsewhere 
Table 1. Estimated total catch of Paralomis spinosissima during biological sampling from catches of the F/V Pro Surveyor. Commercial size crabs were males exceeding $100 \mathrm{~mm}$ carapace width (ca $82 \mathrm{~mm}$ length).

\begin{tabular}{lrrrrrr}
\hline \hline & \multicolumn{2}{c}{$\begin{array}{c}\text { South Georgia } \\
\text { Island }\end{array}$} & \multicolumn{2}{c}{$\begin{array}{c}\text { Shag } \\
\text { Rocks }\end{array}$} & \multicolumn{2}{c}{ Grand } \\
total \\
\cline { 2 - 8 } Item & Sampled & Total & Sampled & Total & Sampled & Total \\
\hline Pot strings & 46 & 138 & 7 & 13 & 53 & 151 \\
Commercial & 451 & 51,728 & 8 & 758 & 459 & 52,486 \\
Discarded & 4,519 & 83,239 & 908 & 8,203 & 5,427 & 96,390 \\
Total & 4,970 & 124,567 & 916 & 8,961 & 5,886 & 133,528 \\
\hline
\end{tabular}

(Otto \& MacIntosh, 1996). There was some emphasis on collecting data necessary to determine size at maturity, because it was required that $\mathrm{U}$. S. observers determined minimum size limits that were at least $10 \%$ greater than the size at maturity. For this reason, we collected morphometric data from almost all sampled crabs for studies of allometric changes. Other observations were simply intended to elucidate general or descriptive aspects of $P$. spinosissima biology. We reiterate some information contained in a previous report (Otto \& MacIntosh, 1996) in order to provide a synopsis but concentrate here on previously unreported observation of parasitology and reproductive characteristics.

\section{DATA COLLECTION}

All crabs described in this report were sampled from pots. Pots were the shape of truncated cone with a steel frame covered by 10 $\mathrm{cm}$ nylon mesh. A funnel-shaped nylon opening in the top of the pot extending into the pot allowed entry of crabs and served as a collar to prevent their escape. Pot dimensions were 1.5 $\mathrm{m}$ diameter for the bottom, $0.9 \mathrm{~m}$ diameter at the top and $0.8 \mathrm{~m}$ in height. The retaining collar was approximately $0.7 \mathrm{~m}$ diameter. Some 660 pots were fished in each $24 \mathrm{hrs}$ period, attached at approximately $47 \mathrm{~m}$ intervals to 12 separate ground lines or "strings" of gear. It is unlikely that the pots used prevented larger specimens from being captured but small crabs may have been able to escape through the mesh.

Most fishing, hence sampling, took place just north of South Georgia Island, but two days were also spent exploring the area near Shag Rocks. While success varied considerably, $P$. spinosissima occurred in all strings. The locations fished were exploratory or conditioned on the catches of large male crabs. We refer to large males $(>100 \mathrm{~mm}$ carapace width or ca $82 \mathrm{~mm}$ length) as "commercial crabs" below. Locating concentrations of commercial crabs resulted in some sustained fishing effort. Our sampling was potentially influenced by the success on commercial fishing although we attempted to concentrate sampling effort on strings in newly fished areas. Macpherson (1988) gives a depth range of 132 to $650 \mathrm{~m}$ for $P$. spinosissima, but the F/V Pro Surveyor caught them from 200 to $830 \mathrm{~m}$.

We estimated total catch of $P$. spinosissima taken during our sampling period by extrapolating from sampled strings to the total number of strings fished (Table 1). We sampled 46 of 138 strings fished near South Georgia Island (33\%) and 7 of 13 strings at Shag Rocks $(54 \%)$. For each pot, the crew counted the number of commercial crabs that were retained for processing and reported the counts to the bridge where they were recorded. For each sampled string, we tabulated the numbers of $P$. spinosissima that were captured. The ratio of discarded crabs to commercial-size crab in sampled strings was used to estimate the number of discards in unsampled strings.

We sampled two to five crabs from each successful pot lift. Data collected from each sampled crab included sex, shell condition, length, width, weight, egg condition, clutch 

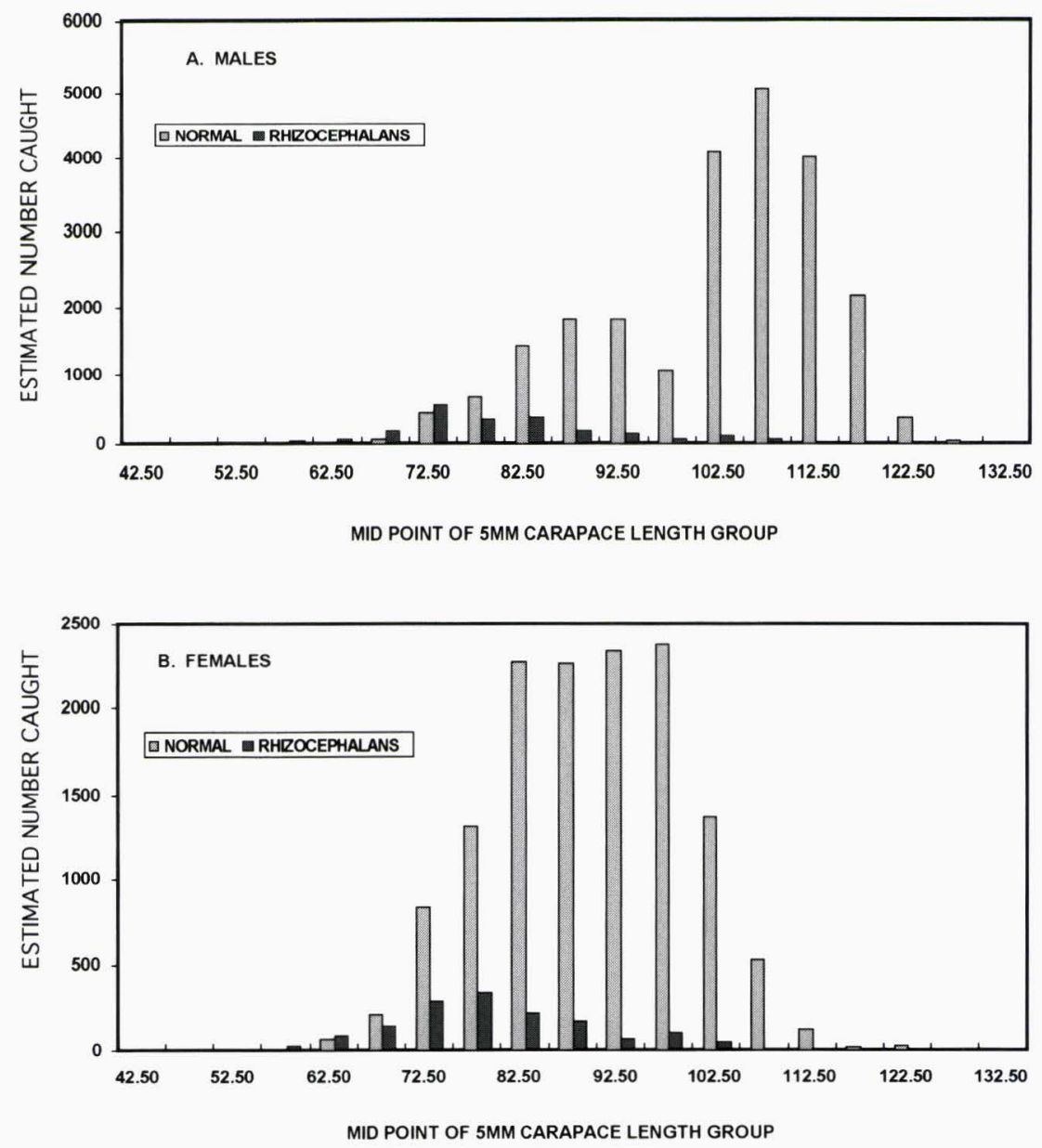

Fig. 1. Estimated carapace length frequency distributions for normal and parasitized male (A) and female (B) Paralomis spinosissima collected from waters near South Georgia Island.

size, egg color, merus length, chela height and presence of parasites or diseases. Every sampled crab was examined and scored for the presence of rhizocephalan externa or resulting scars. Sampling was representative of the sizes of crab taken except that we deliberately sampled all small crabs $(\mathrm{ca}<70 \mathrm{~mm}$ carapace length). Small crabs were uncommon in the catch but important for estimating size at maturity. To a small extent, size-frequency distributions (Figs. 1, 2) may tend to overestimate the frequency of small crabs in the catch. Other biological samples include clutches from ovigerous females, ovaries and a suite of tissues for pathological examination.

\section{RESULTS AND DISCUSSION}

\section{A brief synopsis of general biological data}

What follows are some results from Otto \& MacIntosh (1996) that are pertinent to the present discussion. Basic sampling data and morphometric data are reiterated in Tables 13 to facilitate discussion. For both sexes, the prevalence of rhizocephalans on small crabs made it difficult to collect sufficient numbers of normal immature crabs. The frequency of oldshelled crab becomes appreciable soon after maturity and then tends to increase with size. This pattern is also typical of North Pacific lithodid crabs. Anecdysis also appears to begin 

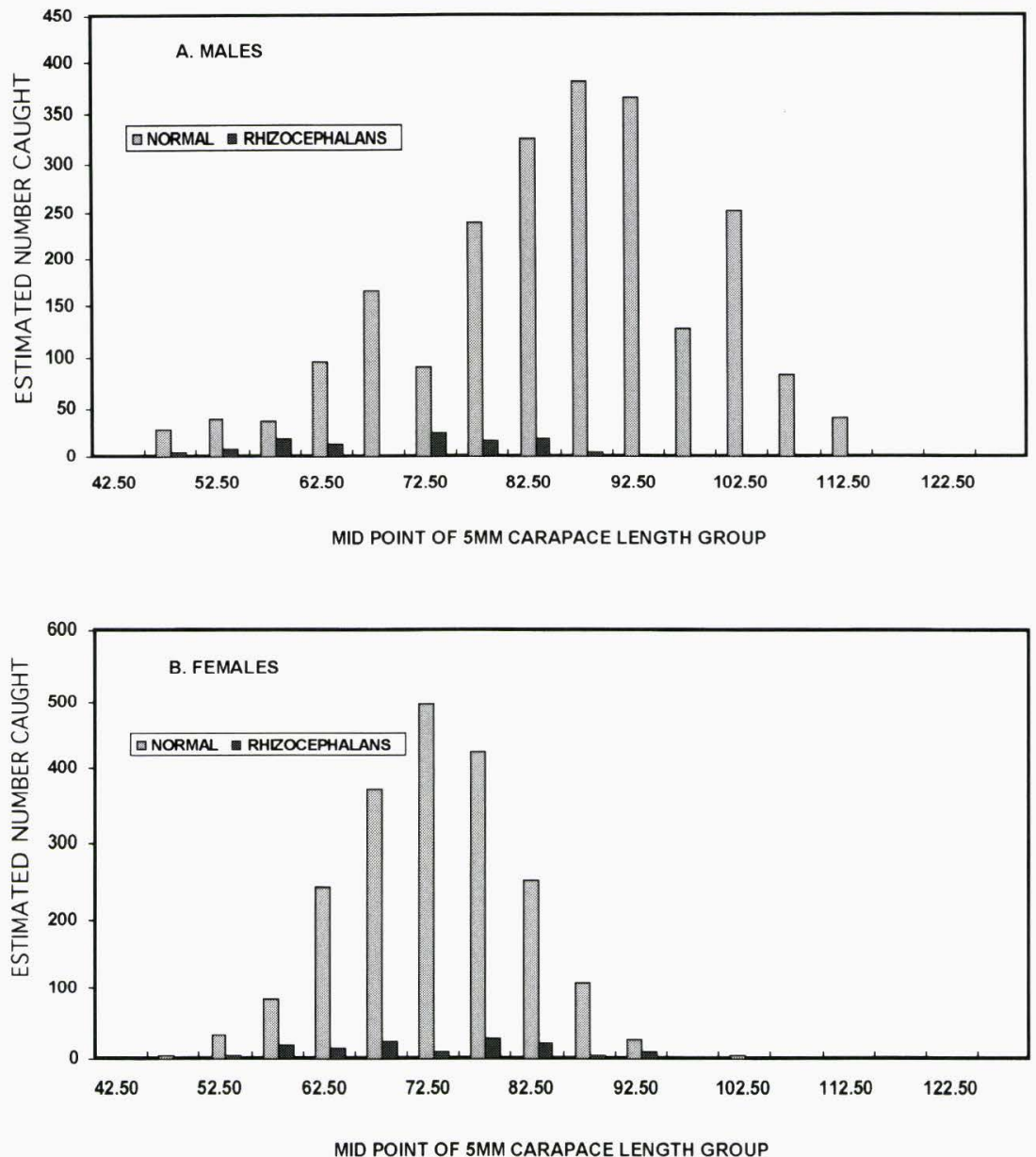

Fig. 2. Estimated carapace length frequency distributions for normal and parasitized male (A) and female (B) Paralomis spinosissima collected from waters near Shag Rocks.

at smaller sizes at Shag Rocks than at South Georgia Island. While other morphometric data were taken, here we report only on relationships involving length (posterior of eye socket to median posterior of carapace), carapace width (including marginal spines) and chela height (see below). Linear regression parameters for width to length and the natural logarithms of length to weight are presented in Table 3. Biologists normally use carapace length to represent size, because it is less subject to measurement error than carapace width. Fishermen and regulatory agencies mostly use carapace width including spines, because it is faster to gauge width than length in determining whether a crab is of legal size. Regressions of carapace width on length are nearly identical for all categories of $P$. spinosissima. The regression of length on width for normal males is most important below. The regression of weight on length is obviously important relative to the size of crab in a fishery, but also of interest, because it indicates changes in morphometry that accompanies rhizocephalan infection.

Size at sexual maturity was undescribed in P. spinosissima and priority was given to the collection and analysis of pertinent data so 
Table 2. Mean, standard error and number of carapace lengths ( $\mathrm{mm})$ for Paralomis spinosissima sampled at South Georgia Island and Shag Rocks.

\begin{tabular}{|c|c|c|c|c|c|c|}
\hline & & $\begin{array}{c}\text { South } \\
\text { Georgia }\end{array}$ & $\begin{array}{l}\text { Shag } \\
\text { Rocks }\end{array}$ & $\begin{array}{c}\text { Mean } \\
\text { difference }\end{array}$ & $t$ & $p$ \\
\hline $\begin{array}{l}\text { Normal } \\
\text { Males }\end{array}$ & $\begin{array}{c}\text { Mean } \\
\text { S.E. } \\
N\end{array}$ & $\begin{array}{r}93.5 \\
0.3 \\
1768\end{array}$ & $\begin{array}{r}82.9 \\
0.5 \\
473\end{array}$ & $\begin{array}{r}10.6 \\
0.6\end{array}$ & 18.3 & $<0.001$ \\
\hline $\begin{array}{l}\text { Males with } \\
\text { Rhizocephalans }\end{array}$ & $\begin{array}{c}\text { Mean } \\
\text { S.E. } \\
N\end{array}$ & $\begin{array}{r}80.4 \\
0.5 \\
489 \\
\end{array}$ & $\begin{array}{r}67.2 \\
2.3 \\
29 \\
\end{array}$ & $\begin{array}{r}13.2 \\
2.4\end{array}$ & 13.2 & $<0.001$ \\
\hline $\begin{array}{l}\text { Difference } \\
\text { from normal }\end{array}$ & $\begin{array}{c}\text { Mean } \\
\text { S.E. } \\
t \\
p\end{array}$ & $\begin{array}{r}13.1 \\
0.5 \\
24.4 \\
<0.001 \\
\end{array}$ & $\begin{array}{r}15.7 \\
2.4 \\
6.5 \\
<0.001 \\
\end{array}$ & & & \\
\hline $\begin{array}{l}\text { Males with } \\
\text { Microsporidans }\end{array}$ & $\begin{array}{c}\text { Mean } \\
\text { S.E. } \\
N \\
\end{array}$ & $\begin{array}{r}88.8 \\
2.5 \\
10 \\
\end{array}$ & $\begin{array}{r}90.0 \\
- \\
1\end{array}$ & -1.2 & - & $\mathrm{NS}$ \\
\hline $\begin{array}{l}\text { Difference } \\
\text { from normal }\end{array}$ & $\begin{array}{c}\text { Mean } \\
\text { S.E. } \\
t \\
p\end{array}$ & $\begin{array}{r}4.7 \\
2.5 \\
1.9 \\
\text { NS }\end{array}$ & $\frac{-}{-}$ & & & \\
\hline $\begin{array}{l}\text { Normal } \\
\text { Females }\end{array}$ & $\begin{array}{c}\text { Mean } \\
\text { S.E. } \\
N \\
\end{array}$ & $\begin{array}{r}89.3 \\
0.2 \\
2347 \\
\end{array}$ & $\begin{array}{r}72.5 \\
0.4 \\
397 \\
\end{array}$ & $\begin{array}{r}16.8 \\
0.5\end{array}$ & 36.5 & $<0.001$ \\
\hline $\begin{array}{l}\text { Females with } \\
\text { Rhizocephalans }\end{array}$ & $\begin{array}{c}\text { Mean } \\
\text { S.E. } \\
N\end{array}$ & $\begin{array}{r}78.9 \\
0.6 \\
340\end{array}$ & $\begin{array}{r}70.4 \\
2.4 \\
29\end{array}$ & $\begin{array}{l}8.5 \\
2.3\end{array}$ & 3.7 & $<0.001$ \\
\hline $\begin{array}{l}\text { Difference } \\
\text { from normal }\end{array}$ & $\begin{array}{c}\text { Mean } \\
\text { S.E. } \\
t \\
p\end{array}$ & $\begin{array}{r}10.4 \\
0.7 \\
16.1 \\
<0.001\end{array}$ & $\begin{array}{l}2.0 \\
2.3 \\
0.9 \\
\text { NS }\end{array}$ & & & \\
\hline $\begin{array}{l}\text { Females with } \\
\text { Microsporidans }\end{array}$ & $\begin{array}{c}\text { Mean } \\
\text { S.E. } \\
N\end{array}$ & $\begin{array}{r}85.3 \\
2.1 \\
16\end{array}$ & $\begin{array}{r}79.0 \\
2.0 \\
2\end{array}$ & 6.3 & 2.7 & NS \\
\hline $\begin{array}{l}\text { Difference } \\
\text { from normal }\end{array}$ & $\begin{array}{c}\text { Mean } \\
\text { S.E. } \\
t \\
p\end{array}$ & $\begin{array}{l}4.1 \\
2.1 \\
1.9 \\
\text { NS }\end{array}$ & $\begin{array}{l}- \\
\overline{\mathrm{NS}}\end{array}$ & & & \\
\hline
\end{tabular}

that appropriate size limits could be set. For females, the size at maturity can be determined by plotting the proportion of females that are ovigerous (including empty egg cases) against size and determining the point at which $50 \%$ are mature (SM50). For males, this determination is made by examining allometric relationships between the sizes of body parts relative to carapace length. The usual method employs the fact that mature male crabs have relatively larger chela (claws) than immature crabs. Analytical methods developed by Somerton (1980) were used to analyze chela allometry. Similar analyses for north Pacific Lithodes spp. include Somerton \& MacIntosh (1983), Somerton \& Otto (1986), and Otto \& Cummiskey (1985).

Plots of the proportion of mature $P$. spinosissima females against size were analyzed using weighted, iterative regression (Otto \& MacIntosh, 1996) with the following results. Unfortunately, insufficient numbers of 


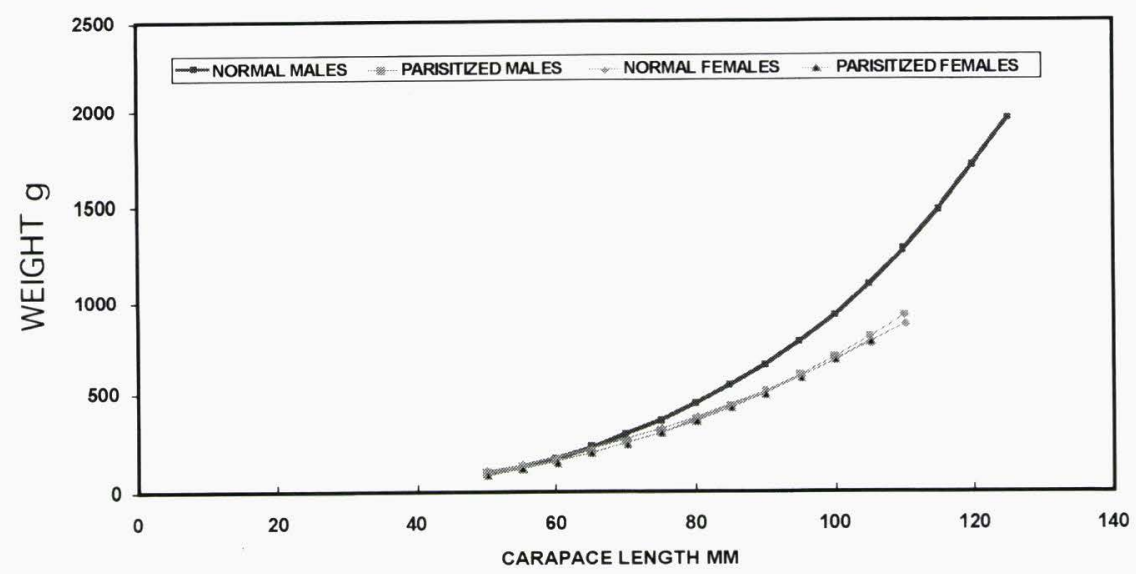

Fig. 3. Summary of carapace length to total wet body weight for Paralomis spinosissima collected from South Georgia Island and Shag Rocks. Lines for females, parasitized males and parasitized females are nearly identical.

small females were available at South Georgia Island and the fitted logistic curve failed to describe the data. For this reason, the Shag Rocks and South Georgia Island data were combined to determine SM50 $=61.7 \mathrm{~mm}(\mathrm{~s}=$ $4.3 \mathrm{~mm}$ ). However, this may be more reflective of conditions at Shag Rocks than at South Georgia Island, because females at Shag Rocks were significantly smaller than those at South Georgia Island (Table 2), and this was true of ovigerous females as well (Figs. 1,2). The size frequency of normal ovigerous females at South Georgia Island was noticeably skewed, however, probably reflecting the prevalence of rhizocephalans. Further, some of the apparently normal females may have had early stages of infection that would not be evident in gross examination. Data presented in Fig. 4 suggest that female SM50 lies near $65 \mathrm{~mm}$ carapace length for South Georgia Island samples and near $60 \mathrm{~mm}$ carapace length for those from Shag Rocks. While we believe that SM50 at South Georgia Island is greater than that at Shag Rocks, further research will be necessary to quantify this difference.

Size at maturity for $P$. spinosissima males

Table 3. Linear regression parameters calculated for Paralomis spinosissima from South Georgia Island and Shag Rocks.

\begin{tabular}{|c|c|c|c|c|c|c|c|c|}
\hline & \multicolumn{4}{|c|}{$\begin{array}{l}\text { Length to width } \\
\mathrm{L}=\mathrm{a}+\mathrm{b} \mathrm{W}\end{array}$} & \multicolumn{4}{|c|}{$\begin{array}{c}\log _{e} \text { weight to } \log _{e} \text { length } \\
\quad \ln (W)=a+b \ln (L)\end{array}$} \\
\hline & $n$ & $a$ & $\mathrm{~b}$ & $R^{2}$ & $n$ & $a$ & $\mathrm{~b}$ & $R^{2}$ \\
\hline \multicolumn{9}{|c|}{ South Georgia Island: } \\
\hline Normal male & 509 & 10.86 & 0.96 & 0.94 & 435 & -8.66 & 3.36 & 0.98 \\
\hline Parasitized & 189 & 4.96 & 1.04 & 0.94 & 159 & -7.14 & 2.97 & 0.97 \\
\hline Normal female & 337 & 6.18 & 1.00 & 0.94 & 255 & -5.98 & 2.71 & 0.97 \\
\hline Parasitized & 118 & 5.50 & 1.03 & 0.95 & 105 & -6.84 & 2.90 & 0.98 \\
\hline \multicolumn{9}{|l|}{ Shag Rocks: } \\
\hline Normal male & 211 & 8.26 & 0.99 & 0.96 & 187 & -8.54 & 3.32 & 0.99 \\
\hline Parasitized & 19 & 2.54 & 1.07 & 0.97 & 20 & -6.45 & 2.80 & 0.94 \\
\hline Normal female & 145 & 5.13 & 1.02 & 0.94 & 134 & -6.62 & 2.85 & 0.97 \\
\hline Parasitized & 21 & 0.63 & 1.10 & 0.96 & 20 & -7.43 & 3.02 & 0.98 \\
\hline
\end{tabular}



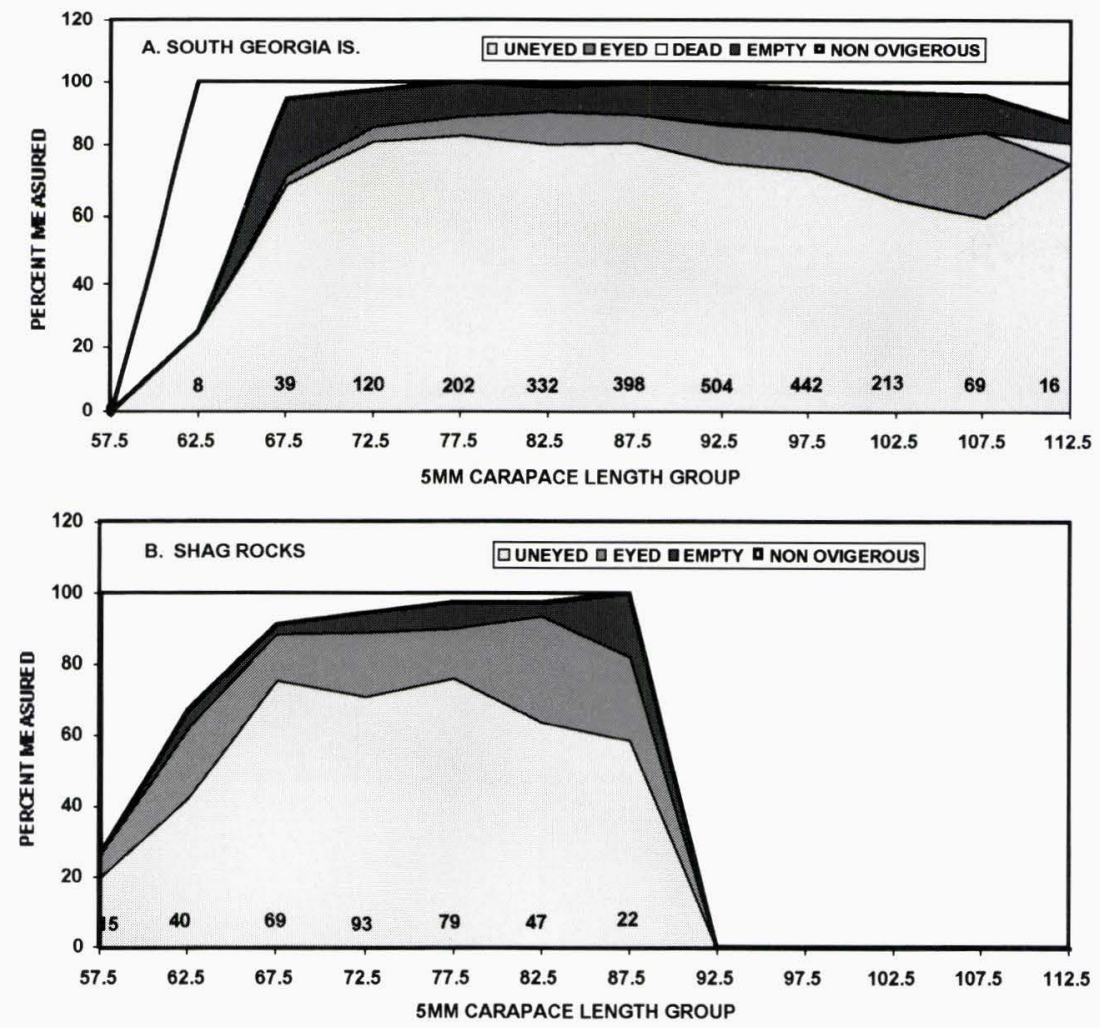

Fig. 4 Summary of embryo condition observed in clutches from for female Paralomis spinosissima collected from South Georgia Island (A) and Shag Rocks (B). Numbers are sample sizes in each carapace length group.

was quantified (Otto \& MacIntosh, 1996) by fitting two regression lines to natural logarithmic plots of chela height against length and searching for the intersection point that minimized the combined residual mean square error (Somerton, 1980). Variances were determined using bootstrap techniques (Somerton \& Otto, 1986). Fitted lines on retransformed axis (see Otto \& MacIntosh, 1996) showed intersections at $74.8 \mathrm{~mm}$ (S.D. $=$
$2.6 \mathrm{~mm}$ ) for South Georgia Island and at 66.4 $\mathrm{mm}($ S.D. $=2.1)$ for Shag Rocks.

\section{Prevalence of parasites, hyperparasites and diseases}

It was immediately obvious that sampled $P$. spinosissima were heavily parasitized by a rhizocephalan previously described as Briarosaccus callosus (Boschma, 1962). Rhizocephalan infections were most prevalent

Table 4 Incidence of rhizocephalan (Briarosaccus callosus) infections in Paralomis spinosissima.

\begin{tabular}{lrrrr}
\hline \hline & Males & Females & Total & \multicolumn{1}{c}{$N$} \\
\hline South Georgia Island & $21.6 \%$ & $12.6 \%$ & $16.7 \%$ & 4,971 \\
Shag Rocks & $6.1 \%$ & $7.1 \%$ & $6.6 \%$ & 915 \\
Combined & $18.8 \%$ & $11.9 \%$ & $15.1 \%$ & 5,886 \\
$N$ & 2,773 & 3,113 & & \\
\hline
\end{tabular}




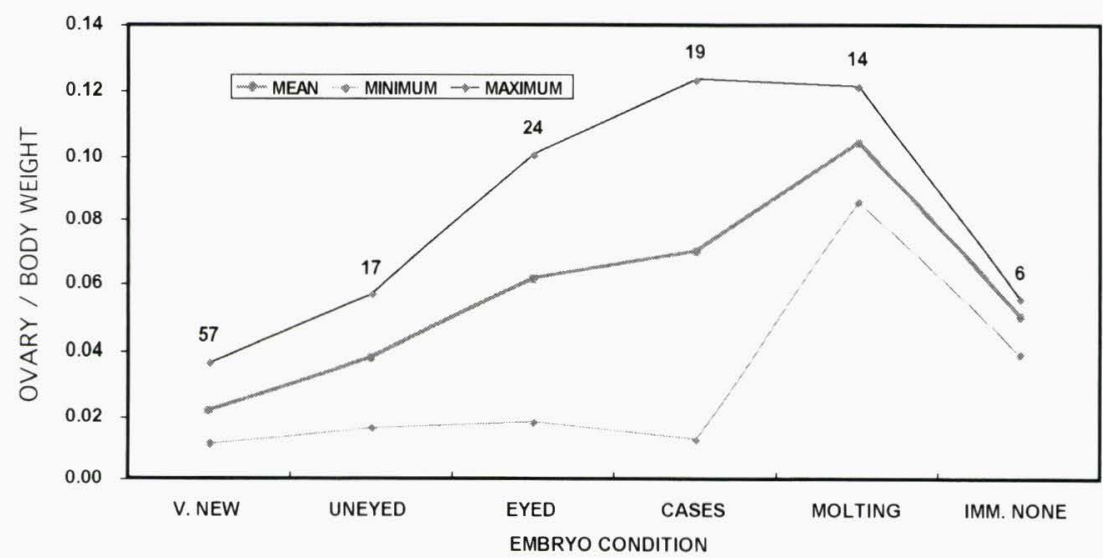

Fig. 5 Summary of gonadosomatic indices for female Paralomis spinosissima collected from South Georgia Island and Shag Rocks. The index increases steadily as the ovary develop form a ground state in crabs soft shells and very new eggs (V.NEW), through that found in crabs with hard shells and more advanced eggs, either uneyed or eyed, and is extremely variable in crabs with empty egg cases after hatching has occurred (CASES). Crabs in the process of molting had the larges indices and fully mature ovaries, while immature crabs (IMM NONE) had intermediate indices suggesting developing ovaries . Numbers in each category are sample sizes.

in small individuals of both sexes (Figs. 1, 2) and were more prevalent at South Georgia Island than at Shag Rocks as well as more prevalent in males than females (Table 4). Small numbers of $P$. spinosissima were also found to be parasitized by a microsporidan that appeared to be similar to a member of the family Nosematidae which infects Lithodes aequispinus in North Pacific waters (Sparks \& Morado, 1985). Specimens of $P$. spinosissima at South Georgia Island were typically larger than those at Shag Rocks, and within each group, those with rhizocephalans were smaller than their normal counterparts (Table 2). The diminished size of parasitized crab almost certainly involves a lower growth rate and likely reflects increased mortality as well.
Hawkes et al. (1985b) show diminished growth in Lithodes aequispinus and Paralithodes platypus that were infected with Briarosaccus callosus. In contrast, crabs parasitized with microsporidans did not differ in size from their normal counterparts and perhaps infect their hosts independently of life stage, although sample sizes are small.

Briarosaccus callosus typically castrates its host which may cause feminization of male crabs (Sparks, 1985). For example, the retransformed relationships in Fig. 3 show that parasitized males resemble females more closely than they do normal males even though the infection destroys the gonads of both sexes. Male crabs with morphology intermediate between infected and normal

Table 5. Incidence of hyperparasitism of Briarosaccus callosus by an un described isopod. Incidence is given relative to number of crabs Paralomis spinosissima with externa that also had at least one externa hyperparasitized.

\begin{tabular}{lrcrr}
\hline \hline & Males & Females & Total & $N$ \\
\hline South Georgia Island & 26.0 & 31.6 & 22.0 & 686 \\
Shag Rocks & $0.0 \%$ & $9.1 \%$ & $4.2 \%$ & 48 \\
Combined & $19.5 \%$ & $22.8 \%$ & $20.8 \%$ & 734 \\
$N$ & 431 & 303 & & \\
\hline
\end{tabular}




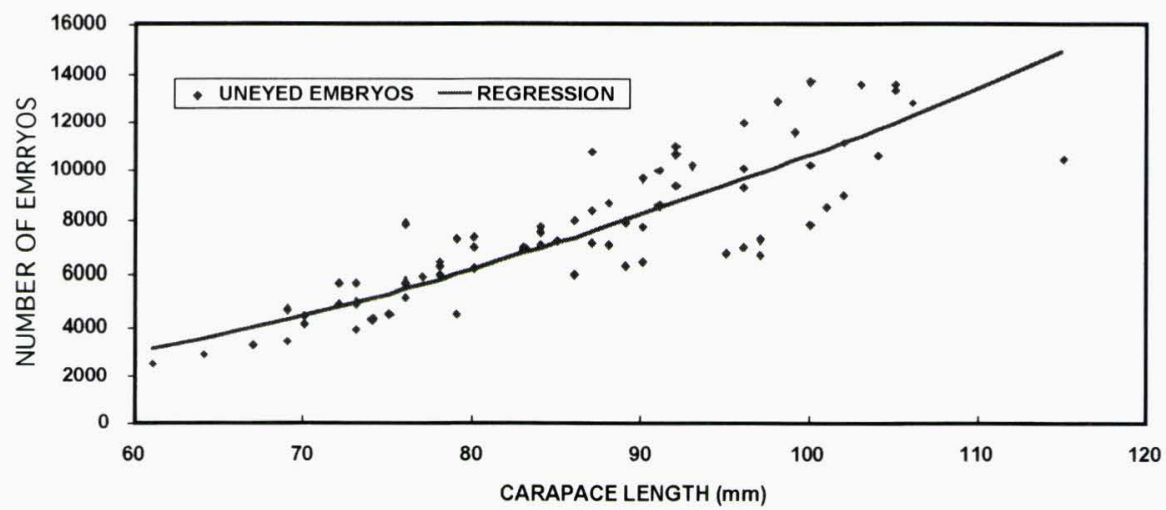

Fig. 6. Relationship of clutch size (E) to carapace length (L) as a measure of fecundity in female Paralomis spinosissima collected from South Georgia Island and Shag Rocks. $\mathrm{E}=0.136 \mathrm{~L}^{2.445}, R=0.89, n=115$.

individuals were not observed, suggesting that effects on morphology occur at the first molt following infection and that crabs may not recover. In a few cases as many as three externa were observed on a single P. spinosissima. Prevalence of rhizocephalan infections is much higher in the South Georgia Island (16.7\%) collections than it is at Shag Rocks $(6.6 \%$, Table 4). Briarosaccus callosus is rarely so prevalent but attacks a variety of lithodid crabs in widely different areas of the world (Boschma, 1930, 1962; Boschma \& Haynes, 1969; Arnaud \& Do-chi, 1977; Hawkes et al., 1985a; Shirley et al., 1985; Somerton, 1981; Macpherson, 1988; Hoggarth, 1990; Pohle, 1992). This literature shows that Briarosaccus callosus infects members of Lithodes, Paralithodes, Paralomis and Neolithodes in the North and South Atlantic, South Pacific and Southern Indian Oceans. The possibility that Briarosaccus callosus is actually a species complex rather than a single species needs investigation.

Briarosaccus callosus, in its turn, is parasitized by an undescribed species of isopod that is a small white sphere partially embedded in the outer surface of the externa but also penetrating into the lumen in some cases. This is probably what Boschma (1962) refers to as "bopyrid ?", but it is clearly not a bopyrid. It may be similar or identical to the isopod mentioned by Pohle (1992) in connection with Neolithodes grimaldi from the North Atlantic. We recorded the number of isopods on a per crab basis and can look at the number of hyperparasites per externs only for crabs with a single externa (Table 5). Of crabs with externa, $20.8 \%$ were hyperparasitized. Prevalence was higher at South Georgia Island than Shag Rocks and higher on females than males. For crabs with single externa at Shag Rocks, only single hyperparasites were observed. At South Georgia Island, 626 crabs had single externa, and $21.6 \%$ of the single externa had hyperparasites, $14.5 \%$ had single infections, $4.1 \%$ had doubles infections, $1.0 \%$ had triple infections and $1.9 \%$ had 4 or more individual hyperparasites. In an extreme case, a single externa collected from South Georgia Island had 21 hyperparasites. The frequency of multiple hyperparasites is higher than would be expected from a geometric series, so perhaps nonrandom events are involved in the infection process. Watters (1998) provides an extensive account of Briarosaccus callosus and its hyperparasites collected from South Georgia Island waters.

\section{Reproductive condition and fecundity}

Observations on the condition of 
embryos suggest that the mating season in $P$. spinosissima is protracted. In part this is indicated by the diversity of embryo types observed for all sizes of females (Fig. 4). Field observations showed that eyed embryos ranged from those that had barely discernable eye spots to fully-formed zoea, hence indicating variable times of extrusion. Shell condition data from females also showed that some were in immediate pre-molt condition and some were soft-shelled, newly-molted crab. These two categories, however, made up less than $20 \%$ of the females observed. The vast majority of females were those with new, hard shells and uneyed eggs. Many females with empty egg cases attached to their pleopods were also encountered, and 35 of these were being grasped by males in a typical pre-mating embrace. In all cases, male members of the pair were larger than their mates. Grasped females were all in pre-molt condition as determined by well-formed second shells. Dissection of females with empty egg cases or hatching embryos showed that their ovaries, and contained oocytes, were large, hence indicating that molting and mating would occur soon. Oocyte diameters in 14 premolt females ranged from 1.9 to $2.1 \mathrm{~mm}$ and averaged $2.0 \mathrm{~mm}$. Assuming that the duration of embryo development is about one year, these observations also suggest that spawning occurs annually. In general, our observations suggest that molting and mating among females are an annual events but do not occur at a fixed time of year. Further observations will be necessary to determine how protracted the molting-mating period is and whether there is any seasonal component to it.

The gonadosomatic index (GSI, ovary weight to calculated body weight) increased regularly from near the time of extrusion and mating until hatching is complete and the cycle is repeated (Fig. 5). GSI is about 0.02 when very new external eggs (V. NEW) are present, and this is basically a spent ovary that is even smaller than that seen in immature females with developing ovaries (Fig. 5 far right). The GSI increases linearly to an average of
0.06 when the embryos have developed eye spots detectable by gross examination and also becomes more variable reflecting that the eyed egg stage has a fairly long duration during which ovarian growth is occurring. After hatching when empty egg cases are observed in the pleopods toe GSI becomes extremely variable, but its range include fully developed ovaries as judged by the GSI of females that are in the process of molting when the GSI averages 0.10 and ranges from 0.9 to 1.2 and oocytes average $2.0 \mathrm{~mm}$ diameter $($ S.D. $=0.05)$. External eggs that contain the developing embryos are approximately prolate spheroids with a major axis averaging $2.08 \mathrm{~mm}$ (S.D. $=0.07)$ and a minor axis averaging 1.88 $($ S.D. $=0.06)$, which yields a volume of 3.88 cubic $\mathrm{mm}(\mathrm{S} . \mathrm{D} .=0.33)$. External eggs change in shape as the embryo develops but do not increase in size. Embryos of $P$. spinosissima are considerably larger than those of Paralithodes spp. but smaller than those of Lithodes spp. In appearance, eggs are orange and exceedingly rich in fats suggesting that $P$. spinosissima larvae may be capable of lecithotrophic development.

The relationship between fecundity as measured by the number of eggs contained in clutches of uneyed eggs (Fig. 6) indicates that $P$. spinosissima do not have a large reproductive potential. Regression analysis indicates that fecundity is about 1,300 embryos at $60 \mathrm{~mm}$ carapace length (near SM50) and would be 9,900 embryos at $115 \mathrm{~mm}$ carapace length. This is less than observed for North Pacific Lithodes spp. (Otto \& Cummiskey, 1985; Somerton, 1981). This leads us to suspect that the life history strategy of $P$. spinosissima is towards the $\mathrm{K}$ end of the $\mathrm{r}-\mathrm{K}$ scale and that regulation of developing fisheries for this resource and possibly other deep water members of the genus should be conservative.

Acknowledgements. - This research would not have been possible without the very gracious help and cooperation of Paul Duffy, Golden Shamrock Inc and the entire crew of the F/V Pro surveyor. We thank Gary Duker, 
Akira Asakura and an anonymous reviewer for helpful comments during review.

\section{LITERATURE CITED}

Arnauld, P.M., \& Do-Chi, T., 1977. Biological and biometrical data on the lithodid crab Lithodes murrayi (Crustacea Decapoda Anomura) of Crozet Island (SW Indian Ocean). Marine Biology, 39: 147-159

Boschma, H., 1930. Briarosaccus callosus, a new genus and new species of rhizocephalan parasite of Lithodes agassizii Smith. Proceedings of the United States National Museum, 17: 1-8.

Boschma, H., 1962. Rhizocephala. Discovery Reports, 33: 55-92.

Boschma, H., \& Haynes, E., 1969. Occurrence of the rhizocephalan Briarosaccus callosus Boschma in the king crab Paralithodes camtschatica (Tilesius) from the northeastern Pacific Ocean. Crustaceana, 16: 97-98.

Eastman, J. T., 1993. Antarctic Fish Biology: Evolution in a Unique Environment. 322 pp., Academic Press, San Diego.

Hawkes, C. R., Myers, T. R., \& Shirley, T. C., 1985. Parasitism of the blue king crab, Paralithodes platypus (Brandt), by the rhizocephalan Briarosaccus callosus Boschma. Journal of Invertebrate Pathology, 45: 252-253.

Hawkes, C. R.,Shirley, T. C., \& Myers, T. R., 1985. Length-weight relationship of blue, Paralithodes platypus, and golden, Lithodes aequispina, king crabs parasitized by the rhizocephalan, Briarosaccus callosus Boschma, Fishery Bulletin, 84: 327-332.

Hoggarth, D. D., 1990. The effects of parasitisim by the rhizocephalan Briarosaccus callosus Boschma in the lithodid crab Paralomis granulosa (Jaquinot) in the Falkland Islands. Crustaceana, 59: 156-170.

Macpherson, E., 1988. Revision of the family Lithodidae Samouelle, 1819 (Crustacea, Decapoda, Anomura) in the Atlantic Ocean. Monografias de Zoologica Marina, 2: 9-153.

Otto, R. S., \& Cummiskey, P. A., 1985. Observations on the reproductive biology of golden king crab (Lithodes aequispina) in the Bering Sea and Aleutian Islands. In: Proceedings of the International King Crab Symposium. University of Alaska Sea Grant Report No. 85-12: 123-136.

Otto, R. S., \& MacIntosh, R. A., 1996. Observations on biology of the lithodid crab Paralomis spinosissima from the southern ocean near
South Georgia Island. In: Proceedings of the International Symposium on Biology, Management and Economics of Crabs from High Latitude Habitats. University of Alaska Sea Grant Report No. 96-02, pp. 627-648.

Pohle, G. W., 1992. First record of the rhizocephalan Briarosaccus callosus (Cirreiedia, Peltogasteridae) infecting the Atlantic porcupine crab, Neolithodes grimaldi (Decapoda, Anomura, Lithodidae). Crustaceana, 62: 133-136.

Shirley, S. M., Shirley, T. C., \& Meyers, T. R., 1985. Hymolymph studies of the blue (Paralithodes platypus) and golden (Lithodes aequispina) king crab parasitized by the by the rhizocephalan barnacle, Briarosaccus callosus. In: Proceedings of the International King Crab Symposium. University of Alaska Sea Grant Report No. 85-12, pp. 341-352.

Somerton, D. A. 1980. A computer technique for estimating the size of sexual maturity in crabs. Canadian Journal of Fisheries and Aquatic Sciences, 37: 1488-1494.

Somerton, D. A. 1981. Contribution to the life history of the deep-sea king crab, Lithodes couesi, in the Gulf of Alaska. Fishery Bulletin, 79: 259-269.

Somerton, D.A., \& MacIntosh, R. A., 1983. The size at sexual maturity of blue king crab, Paralithodes platypus, in Alaska. Fishery Bulletin, 81: 621628.

Somerton, D.A., \& Otto, R. S., 1986. Distribution and reproductive biology of the golden king crab, Lithodes aequispina, in the Eastern Bering Sea. Fishery Bulletin, 84: 571-584.

Sparks, A. K. 1985. A Synopsis of Invertebrate Pathology Exclusive of Insects. 399 pp., Elsevier. New York.

Sparks, A. K., \& Morado, J. F., 1985. A preliminary report on the diseases of Alaska king crabs. In: Proceedings of the International King Crab Symposium. University of Alaska Sea Grant Report No. 85-12, pp. 333-339.

Watters, G., 1998. Prevalences of parasitizes and hyperparisitized crabs near South Georgia Island. Marine Ecological Progress Series, 170: 215229.

Addresses: *RSO, RAM, National Marine Fisheries Service, Kodiak Laboratory, 301 Research Court, Kodiak, Alaska 99615, U.S.A.; e-mails: (RSO) robert.s.otto@noaa.gov, (RAM) rmacintosh@gci.net

*Author for correspondence 